\title{
Laminin $\alpha 4$-Null Mutant Mice Develop Chronic Kidney Disease with Persistent Overexpression of Platelet-Derived Growth Factor
}

\author{
Christine K. Abrass, ${ }^{* \dagger}$ Kim M. Hansen, ${ }^{\star \dagger}$ \\ and Bruce L. Patton ${ }^{\ddagger}$ \\ From the Primary and Specialty Care Medicine, ${ }^{*}$ Department of \\ Veterans Affairs Puget Sound Health Care System, Seattle, \\ Washington; the Program on Allergy and Inflammation, ${ }^{\dagger} \mathrm{UW}$ \\ Medicine Lake Union, Division of Gerontology and Geriatric \\ Medicine, Department of Medicine, University of Washington \\ School of Medicine, Seattle, Washington; and the Center for \\ Research on Occupational and Environmental Toxicology, ${ }^{\ddagger}$ \\ Oregon Health and Sciences University, Portland, Oregon
}

Each extracellular matrix compartment in the kidney has a unique composition, with regional specificity in the expression of various laminin isoforms. Although null mutations in the majority of laminin chains lead to specific developmental abnormalities in the kidney, Lama4-/- mice have progressive glomerular and tubulointerstitial fibrosis. These mice have a significant increase in expression of platelet-derived growth factor (PDGF)-BB, PDGF-DD, and PDGF receptor $\beta$ in association with immature glomerular and peritubular capillaries. In addition, mesangial cell exposure to $\alpha 4$-containing laminins, but not other isoforms, results in down-regulation of PDGF receptor mRNA and protein, suggesting a direct effect of LN411/LN421 on vessel maturation. Given the known role of overexpression of PDGF-BB and PDGF-DD on glomerular and tubulointerstitial fibrosis, these data suggest that failure of laminin $\alpha 4$-mediated down-regulation of PDGF activity contributes to the progressive renal lesions in this animal model. Given the recent demonstration that individuals with laminin $\alpha 4$ mutations develop cardiomyopathy, these findings may be relevant to kidney disease in humans. (Am J Patbol 2010, 176:839-849; DOI: 10.2353/ajpath.2010.090570)

Laminin (LN) is a large, heterotrimeric, cruciform molecule composed of $\alpha, \beta$, and $\gamma$ subunits. ${ }^{1}$ Five distinct $\alpha$ (LAMA1-5), $3 \beta$ (LAMB1-3), and $3 \gamma$ (LAMC1-3) chains $^{1,2}$ variably assemble to create distinct isoforms ${ }^{3}$ that are temporally and spatially regulated, and each conveys a variety of biological functions. ${ }^{4-11}$ The $L N \alpha 4$-containing isoforms, LN411 $(\alpha 4 \beta 1 \gamma 1)$ and LN421 ( $\alpha 4 \beta 2 \gamma 1)$, are abundant in microvessels. Studies of LN $\alpha 4$-deficient mutant mice (lama4-/-) reveal that although $\alpha 4$-LNs are not required for blood vessel formation, they play important roles in blood vessel maturation, and in stabilization of vessels that form with injury, inflammation and tumor growth. ${ }^{7,12,13}$ In vitro studies indicate that $\alpha 4$ LNs directly regulate endothelial cell proliferation and inhibit apoptosis. ${ }^{14} \alpha 4$-LNs are produced by endothelial cells in most microvessels; however, endothelial cells in the renal glomerulus do not express $\mathrm{LN} \alpha 4$-containing isoforms. ${ }^{15} \mathrm{In}$ stead, LN411 and LN421 at the endothelial-mesangial interface are produced by the mesangial cells (MCs). ${ }^{15}$ Platelet-derived growth factor (PDGF) is the primary growth factor responsible for MC proliferation and migration during glomerulogenesis, ${ }^{16}$ and we have shown that PDGF-induced MC migration requires $L N \alpha 4 .{ }^{15}$ This function could not be replaced by LN111 or LN511/521. ${ }^{15}$ Together these observations suggested the possibility that deficiency of $\mathrm{LN} \alpha 4$ might impair the ability of the kidney microvasculature to mature or be repaired in lama4-/- adult mice, resulting in kidney disease despite normal initial development.

Previous reports have documented a spectrum of developmental defects and tissue maintenance defects in lama4-1- mice. Early postal-natal hemorrhage from birth-related trauma to fragile blood vessels occurs in lama4-/- mice; yet, by three-weeks of age, accumulation of $L N \alpha 5$ stabilizes vessels, although they remain dilated. ${ }^{12}$ Vessel fragility recurs when new vessels form

Supported by National Institutes of Health grants (C.K.A., R01 DK49771; B.L.P. NS040759 and NS064397). This work was supported by resources and the use of facilities at the VA Puget Sound Health Care System, Seattle, WA

Accepted for publication October 27, 2009.

Address reprint requests to Christine K. Abrass, M.D., Professor of Medicine, University of Washington School of Medicine, UW Medicine South Lake Union, 815 Mercer Street, Seattle, WA 98109. E-mail: cabrass@u.washington.edu. 
Table 1. Antibodies

\begin{tabular}{llll}
\hline \multicolumn{1}{c}{ Antibody } & Type & Antigen & Source \\
\hline LN $\alpha 1$ & mRat & LN111 & Dr. D. Abrahamson, University of Kansas \\
LN $\alpha 2$ & pRabbit & LAMA2 peptide & Dr. C. Abrass, University of Washington \\
LN $\alpha 3(5 \mathrm{C} 5)$ & mMouse & Rat 804G cells & Dr. J. Jones, Northwestern University \\
LN $\alpha 4$ & pGoat & Mouse LAMA4, AA826-1816 & R \& D Systems Inc. (Minneapolis, MN) \\
LN $\alpha 5(\mathrm{H} 160)$ & pRabbit & LAMA5 peptide & Santa Cruz Biotechnology (Santa Cruz, CA) \\
LN $\beta 1(5 A 2)$ & mRat & LN111 & Dr. D. Abrahamson, University of Kansas \\
LN $\beta 2(H 300)$ & pRabbit & LAMB2 peptide & Santa Cruz Biotechnology \\
LN111 & pRabbit & EHS LN111 & Dr. C. Abrass, University of Washington \\
Collagen IV $(\alpha 3)$ & mMouse & Human & SciMedix (Denville, NY) \\
WT-1 & mMouse & Human & Santa Cruz Biotechnology \\
VWF & pRabbit & Human & Sigma-Aldrich (St. Louis, MO) \\
$\alpha$ SMA & mMouse & Human & Sigma-Aldrich \\
NG2 & mMouse & Rat & Sigma-Aldrich \\
PDGF-BB & pRabbit & Human AA101-116 & Calbiochem (La Jolla, CA) \\
PDGF-R $\beta$ & pRabbit & Human & Upstate, Biotechnology (Lake Placid, NY) \\
PDGF-C & pRabbit & Human & Zymogenetics 3640 (Seattle, WA) \\
PDGF-D & pRabbit & Human & Zymogenetics 3812 \\
VEGF & pRabbit & Human & Santa Cruz Biotechnology \\
Angiopoietin 2 & pGoat & Human & Sigma-Aldrich \\
Activated caspase-3 & pRabbit & Human & Cell Signaling (Danvers, MA) \\
GAPDH & pRabbit & Human & Abcam (Cambridge, MA) \\
\hline
\end{tabular}

in response to injury. ${ }^{12}$ The heart forms normally, but lama4-/- mice develop cardiomyopathy with time. ${ }^{17}$ Neurological dysfunction occurs in lama4-/- mice, through independent defects in organizing presynaptic specializations at neuromuscular synapses, ${ }^{18}$ and in the ability of developing Schwann cells to properly sort and myelinate. ${ }^{19,20}$ This report details the characteristics of kidney abnormalities, including the development of glomerulosclerosis and tubulointerstitial fibrosis over time in lama4-/- mice.

\section{Materials and Methods}

\section{Antibodies}

Polyclonal rabbit antibodies to fibronectin, thrombospondin, EHS LN, LN $\alpha 2$, LN $\alpha 3$, and $\mathrm{LN} \alpha 4$ were developed and characterized as described previously. ${ }^{15,21,22}$ Other antibodies used are listed in Table 1. Alexa Fluor secondary antibodies to mouse and rabbit IgG were purchased from Molecular Probes, Eugene OR. HRPconjugated secondary antibodies to rabbit IgG were purchased from Pierce, Rockford, IL.

\section{Lama4-/- Mouse}

Animal use was per the National Institutes of Health Guide for the Care and Use of Laboratory Animals and approved by the Institutional Animal Care and Use Committees of both the Oregon Health and Sciences University and the VA Puget Sound Health Care System. C57BL/6J mice were purchased from Jackson Laboratories. Lama4 null mice originally obtained from Dr. Karl Tryggvason ${ }^{12}$ were back-crossed for five generations to C57BL/6J mice. ${ }^{18,19}$ Genotypes were confirmed by polymerase chain reaction (PCR) of tail-snip DNA, using sense and anti-sense primers. ${ }^{19}$ Animals examined in- cluded male and female mice, aged 7 weeks to 23 months (wild type, $n=8$; lama4-l-, $n=12$ ).

\section{Renal Function}

Renal function studies were performed on serum and urine samples from 10 wild-type and 10 lama4-/- mice ages $2-11$ months. Urine albumin was measured by enzyme-linked immunosorbent assay using the Albuwell $M$ kit (Exocell Inc., Philadelphia, PA) per the manufacturer's instructions. Serum and urine creatinines were determined using the QuantiChrom creatinine assay kit (DKT500, BioAssay Systems, Hayward, CA). Albumin excretion was expressed as $\mu \mathrm{g}$ albumin/mg creatinine. No differences were observed with either group by age; thus, animals were grouped for statistical comparison.

\section{Histology}

Kidneys were processed for light, electron and fluorescence microscopy by routine methods. ${ }^{23}$ For immunohistochemistry, anti-rabbit ImmPRESS reagent (Vector Laboratories, Burlingame, CA) was used followed by 3,3'-diaminobenzidine and counter staining with hematoxylin performed by the Seattle Mouse Metabolic Phenotyping Center. For fluorescence microscopy, slides were viewed using a Zeiss microscope equipped for epi-illumination. Slides were photographed using a digital RTcolor Spot camera or a Zeiss AxioCam MRM black and white camera. Glomerular diameter was measured using the software contained in Zeiss Axiovision4.5.

\section{Cell Culture}

Cloned rat glomerular MCs (passages 8-12) were cultured without supplemental insulin by modification of rou- 

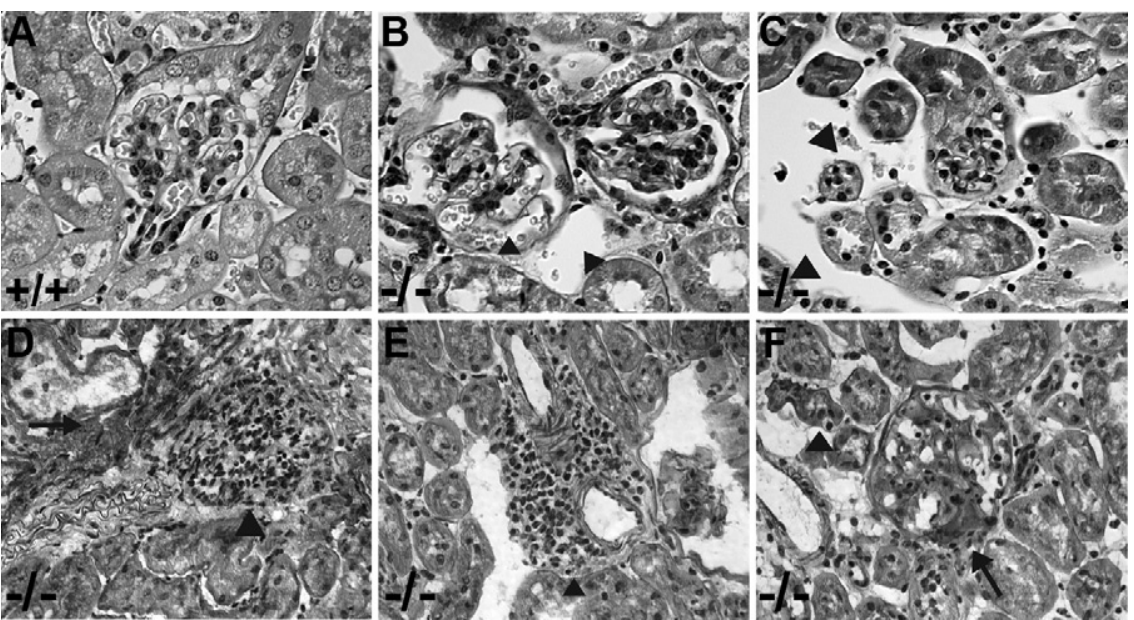

Figure 1. Light microscopy. Paraffin sections were stained with periodic acid-Schiff. Samples from wild-type (wt) (representative glomerulus shown in $\mathbf{A}$ ) and lama4-/- (ko) mice (B and C) at 7 weeks of age and from lama $4-/-$ animals at $6(\mathbf{D}), 9(\mathbf{E})$, and $18(\mathbf{F})$ months of age are shown. Dilated glomerular capillaries (B) and peritubular capillaries (B and $\mathbf{C})$ are shown (arrowheads). Note the proliferative changes in the glomerulus in D (arrowhead), as well as the area of tubulointerstitial fibrosis (arrow). A perivascular inflammatory infiltrate is shown in $\mathbf{E}$ (arrowhead). Glomerulosclerosis (arrow) and tubular atrophy (arrowhead) are apparent in $\mathbf{F}$. No glomerular or tubulointerstitial fibrosis was seen in wild-type mice up to 23 months in age.

tine methods. ${ }^{24-26}$ To assess the role of extracellular matrix composition on PDGF-R $\beta$ expression, MCs were cultured on plates that had previously been coated with LN-111 (isolated from EHS-sarcoma cells, Sigma Chemical, St. Louis, MO) or LN411/421 prepared from MC cultures. ${ }^{15,27}$

\section{$R T-P C R$}

Total RNA was isolated using RNAqueous-4 PCR kit (Ambion, Austin, TX). The RNA was treated with RNase-free DNase, and the reverse transcription reaction was preformed with MuLV reverse transcriptase and oligo(dT) (Applied Biosystems Inc., Foster City, CA). Real-time quantitative PCR was performed using a $\mathrm{ABI} 7900 \mathrm{HT}$ machine and SYBR Green SensiMix dT (Bioline, Taunton, MA). ${ }^{28}$ The following sequences were used for primers: rat PDGF-R $\beta$, 5'-ACACATCAAATACGCGGACA-3' and 5'-GAGCACTGGTGAGTCGTTGA-3'; mouse PDGF-R $\beta$ 5'-CCGGAACAAACACACCTTCT-3' and 5'-TATCCATGTAGCCACCGTCA-3', PDGF-BB, 5'-AAAGGCAAGCACCGAAAGT-3' and 5'-GGGGCAATACAGCAAATACC-3', PDGF-D, 5'-CCCAGGAGAAAACACGGATA-3' and 5'TTCCACAAAGTCATACCTACAAATG-3' and 18s 5'-GACTCAACACGGGAAACCTC-3' and 5'-AGACAAATCGCTCCACCAAC-3'. Primers to GAPDH were purchase from Qiagen, Valencia CA.

\section{Western Blot}

For whole cell lysates, cells were washed with phosphate-buffered saline and extracted in phosphate-buffered saline containing $0.1 \%$ sodium dodecyl sulfate, $0.5 \%$ Triton $\mathrm{X}-100$, and protease inhibitors (Sigma-Aldrich). Western blots using were performed as described. ${ }^{22}$ Densitometry was performed using 1D software (v3.5, Kodak).

\section{Statistical Analysis}

Group means were compared by one-way analysis of variance with subgroup testing by contrasts. $P<0.05$ was considered significant.

\section{Results}

\section{Light Microscopy}

Kidney samples were examined from wild-type and lama4-1- mice from 7 weeks to 23 months of age (Figure 1, A-F). No abnormalities were identified in wild-type mice over the ages examined. In lama4-/- mice aged 7-14 weeks, kidney development is generally normal; yet, glomerular capillary loops and peritubular capillaries are dilated. Consistent with dilated glomerular capillaries, glomeruli in lama4-/- mice were $21 \%$ larger than wildtype mice (glomerular diameter: wild-type: $89.9 \pm 16.9$ $\mu \mathrm{m}$ versus lama4-/- $109.2 \pm 16.3 \mu \mathrm{m}, P<0.01)$. At ages older than 14 weeks, many glomeruli were hypercellular, and areas of perivascular inflammation were evident. With increasing age, sclerotic glomeruli were more common. Areas of tubulointerstitial fibrosis were also present in lama4-/- animals beyond 6 months of age. Fibrotic changes were accompanied by increased staining for collagen, thrombospondin, and fibronectin (not shown). The progressive sequence of these findings suggests that abnormalities in microvessel maturation or repair contribute to accelerated kidney fibrosis as these animals age. Studies were performed to determine whether proteinuria or functional abnormalities were present before the onset of fibrosis. Abnormalities in renal function were not demonstrated up to 11 months of age as serum creatinine values were not different from wildtype mice (wild-type: $0.19 \pm 0.05 \mathrm{mg} / \mathrm{dl}$, lama4-/-: $0.23 \pm 0.07 \mathrm{mg} / \mathrm{dl}, P>0.05)$. Urinary albumin excretion was also not elevated as compared with wild-type mice (wild-type: $0.35 \pm 0.40 \mu \mathrm{g} / \mathrm{mg}$ creatinine; lama4-/-: $0.37 \pm 0.23 \mu \mathrm{g} / \mathrm{mg}$ creatinine, $P>0.05$ ); thus, functional abnormalities that develop later would reflect the increasing degrees of renal scarring.

\section{Electron Microscopy}

Normal glomerular structure in wild-type mice included endothelial cells with fenestrae and podocytes with foot processes. Small arterioles and peritubular capillaries with pericytes were also normal in wild-type mice (Figure 


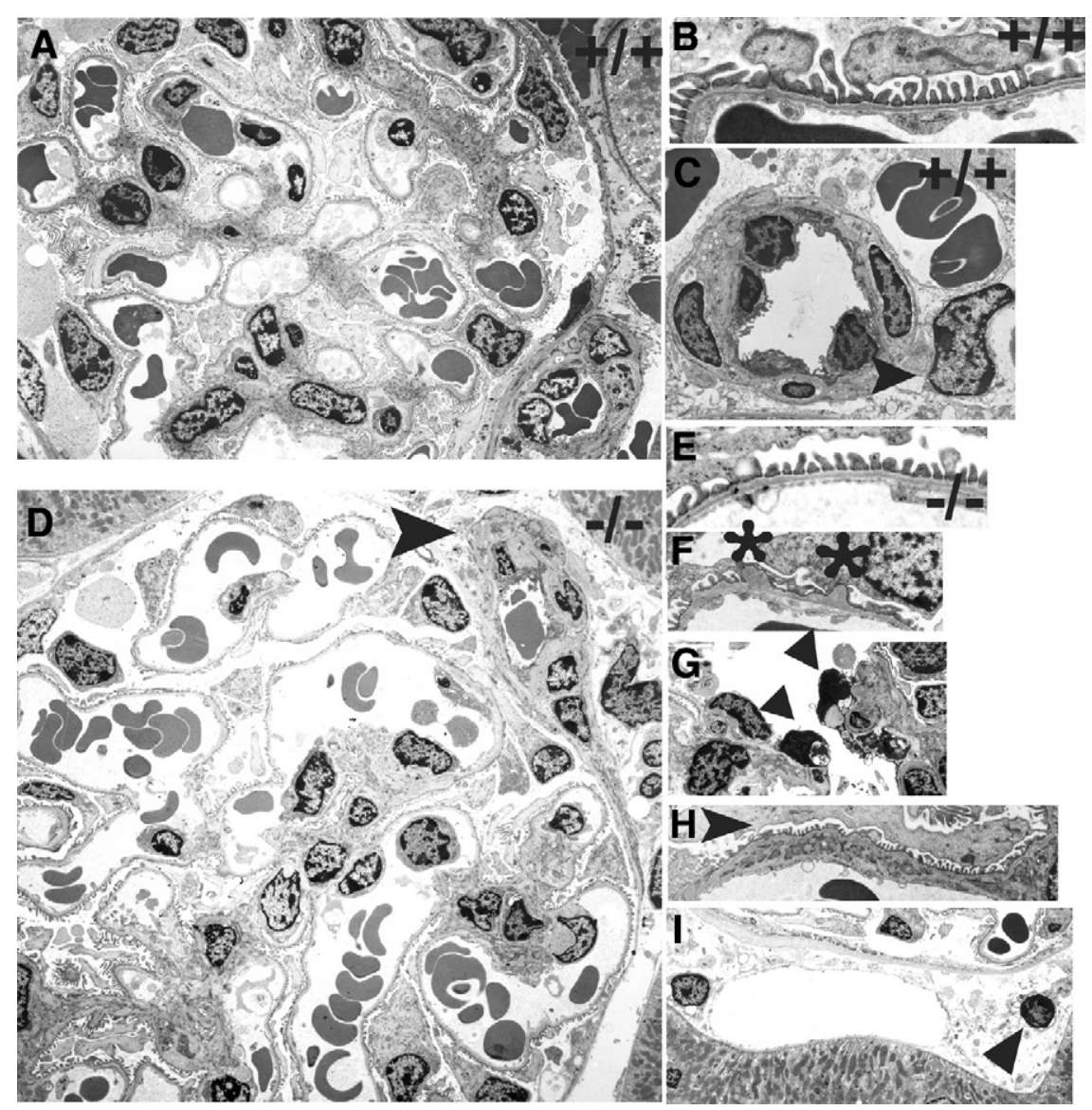

Figure 2. Electron microscopy. Representative electron micrographs from wt (A-C) and (ko) (D-I) mice at 7-14 weeks of age are shown. Normal glomerular structure (A) including podocyte foot processes, GBM, and endothelial fenestrae (B) are shown in wild-type mice. The circumferential pattern of pericyte investment around an arteriole and a pericyte (arrowhead) adjacent to an erythrocyte-filled peritubular capillary is shown in (C). In lama4-/- mice dilated glomerular capillaries are present (D). Also shown in D (arrowhead) is a small arteriole with pericytes and abundant extracellular matrix. Lama4 null mice had normal regions of glomerular capillary wall with normal appearing GBM, podocyte foot processes and endothelial fenestrae similar to wild-type mice (E). Abnormal areas of GBM were also detected where out-pockets of GBM were associated with foot process effacement (F, asterisks). Although glomerular endothelial cells were abundant, apoptotic endothelial cells were also noted (G arrowheads). Areas of mesangial interposition with split basement membranes were also seen in lama4-/- mice (H, arrowhead), as well as dilated peritubular capillaries with nearby and distant pericytes (I, arrowhead).
2, A-C). In contrast, lama4-/- mice (Figure 2, D-I) had enlarged glomeruli with dilated capillary loops. Mesangial cells (MCs) were more prominent at the glomerular hilus, with fewer MCs supporting peripheral capillary loops than normally occurs, and their irregular distribution coincided with irregular and dilated capillary loops. The glomerular capillary wall is generally normal, including podocyte foot processes, endothelial fenestrae and glomerular basement membrane (GBM); however, there were also frequent focal areas with outpockets of GBM. Apoptotic glomerular endothelial cells were identified in glomeruli examined by electron microscopy, and the GBM was split with mesangial interposition at some sites. Peritubular capillaries were dilated in lama4-/- mice, and pericytes were distant from the capillary edge. Small arterioles had increased extracellular matrix (ECM) and multiple pericytes, yet some were not tightly invested. Dilated glomerular capillary loops, GBM outpockets, mesangial interposition and apoptotic endothelial cells are likely harbingers of the sclerosis observed by light microscopy in lama4-/- animals at later ages.

\section{Distribution of Cell Types}

Renal tissue was stained with antibodies to identify podocytes (WT-1), endothelial cells (PECAM CD31, vWF, isolectin B4), and MCs, vascular smooth muscle cells, and pericytes ( $\alpha$-SMA, NG2) (Figures 3 and 4, A-D). Staining showed similar numbers of podocytes and en- dothelial cells in wild-type and lama4-/- mice. The intensity of VWF staining was increased in lama4-/- mice suggesting that endothelial cells are activated. ${ }^{29}$ Using similar methods, Wang et $\mathrm{al}^{17}$ found early loss of microvascular endothelial cells in the heart along with the development of ischemia and cardiofibrosis. Significant differences in endothelial cell numbers were not observed in kidneys in animals 7-14 weeks of age, nor were apoptotic cells detected by staining for activated caspase 3 (less than 1\% of total cells stained positively in either wild-type or lama4-/- mice, data not shown). Although a general increase in the number of apoptotic cells was not demonstrated, the presence of apoptotic glomerular endothelial cells in electron micrographs suggests that processes similar to those demonstrated in the heart may be occurring in the kidney, albeit at a slower rate. In older mice, reduced numbers of endothelial cells were observed in areas of tubulointerstitial fibrosis; thus, in the late stages of interstitial fibrosis, ischemia may contribute to fibrosis as occurs in the heart. ${ }^{17}$

MCs, vascular smooth muscle cells, and capillary pericytes were identified by staining for $\alpha$-SMA and NG2 $2^{30}$ (Figure 3). Glomerular staining indicated the presence of $\mathrm{MCs}$ and their distribution coincided with what was seen by electron microscopy. During development, $\alpha$-SMA is prominent in MCs, as well as afferent and efferent arterioles. Mesangial expression declines as glomerulogenesis is completed. ${ }^{31}$ In contrast to the normal pattern confirmed in wild-type mice, lama4-/- mice had in- 
wt

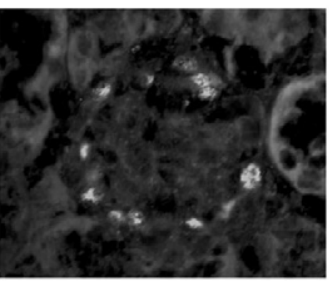

WT-1

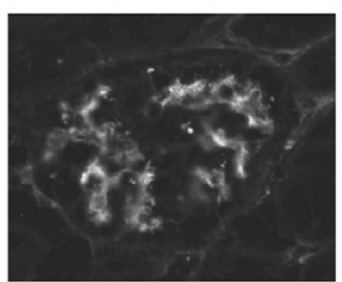

vWF

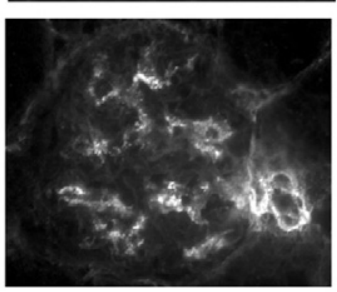

$\alpha \mathrm{SMA}$

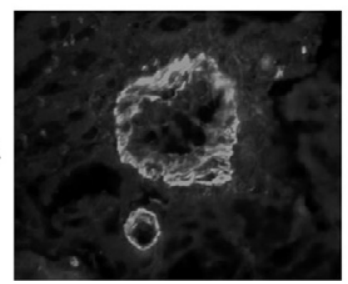

ko
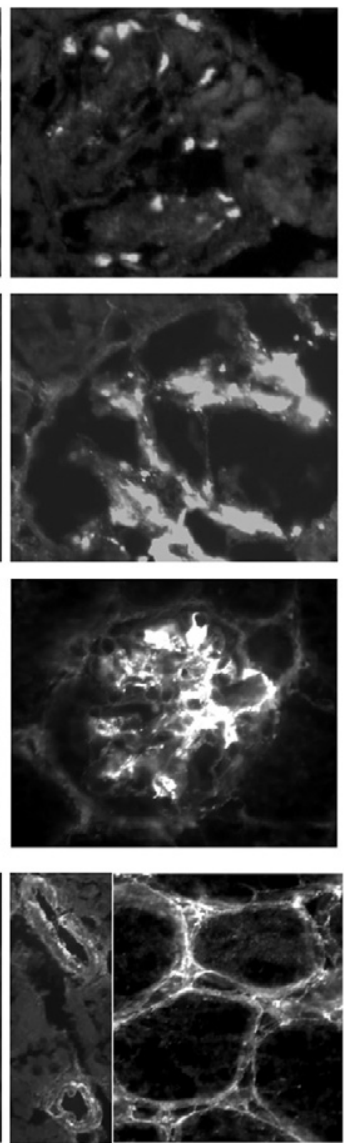

Figure 3. Immunofluorescence microscopy: identification of cells. Samples from wt and ko tissues were stained as indicated. Podocytes were identified by staining for WT-1. Endothelial cells were identified by staining for von Willebrand factor (vWF). Note increased staining with vWF in lama4-/mice indicating endothelial cell activation. Vascular smooth muscle cells and MCs were identified by staining for $\alpha$-smooth muscle actin $(\alpha \mathrm{SMA})$. Note increased $\alpha$ SMA expression in the glomerular hilum and discontinuous staining of arteriole walls of the lama4-/- mice.

creased $\alpha$-SMA staining in the glomerular hilum, and discontinuous staining in the walls of arterioles. In some lama4-/- mice, increased $\alpha$-SMA was noted in cells associated with peritubular capillaries. $\alpha$-SMA staining is normally absent in the interstitium, but has been observed in lesions associated with progressive tubulointerstitial fibrosis. ${ }^{32}$

To further explore the degree of pericyte investment, particularly given the discontinuous staining for $\alpha$-SMA, NG2 (Figure 5, A-F) staining was performed. NG2 was identified throughout the mesangium in wild-type animals, and it was clustered at the hilus in lama4-/- mice, similar to $\alpha$-SMA. In arterioles and peritubular capillaries of wild-type mice, NG2-positive cells formed a tight ring around endothelial cells. Although abundant NG2-positive pericytes surrounded blood vessels in lama4-/mice, they did not tightly encase the vessels. The relationship of these cells to endothelial cells was confirmed by dual staining for CD31 and isolectin B4, which showed a discrete ring of CD31/isolectin B4 positive cells forming the lumen in all animals (not shown). These findings suggested an increase in number of pericytes and mi-

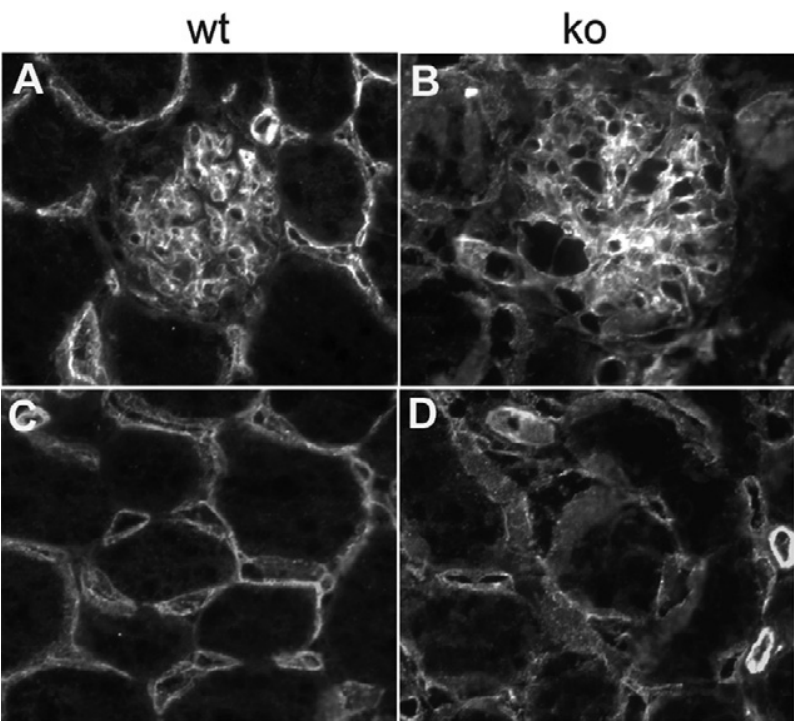

Figure 4. Endothelial cell staining. Endothelial cells were identified by staining with fluorescein-labeled isolectin B4. A and C: Wild-type mice. B and D: Lama4-/- mice.

gration toward the vessel wall; yet, inadequate investment of endothelial cells.

\section{Laminin Subunit Expression in lama4-/- Mice}

Key transitions in LN isoforms occur during normal glomerulogenesis resulting in unique composition in each

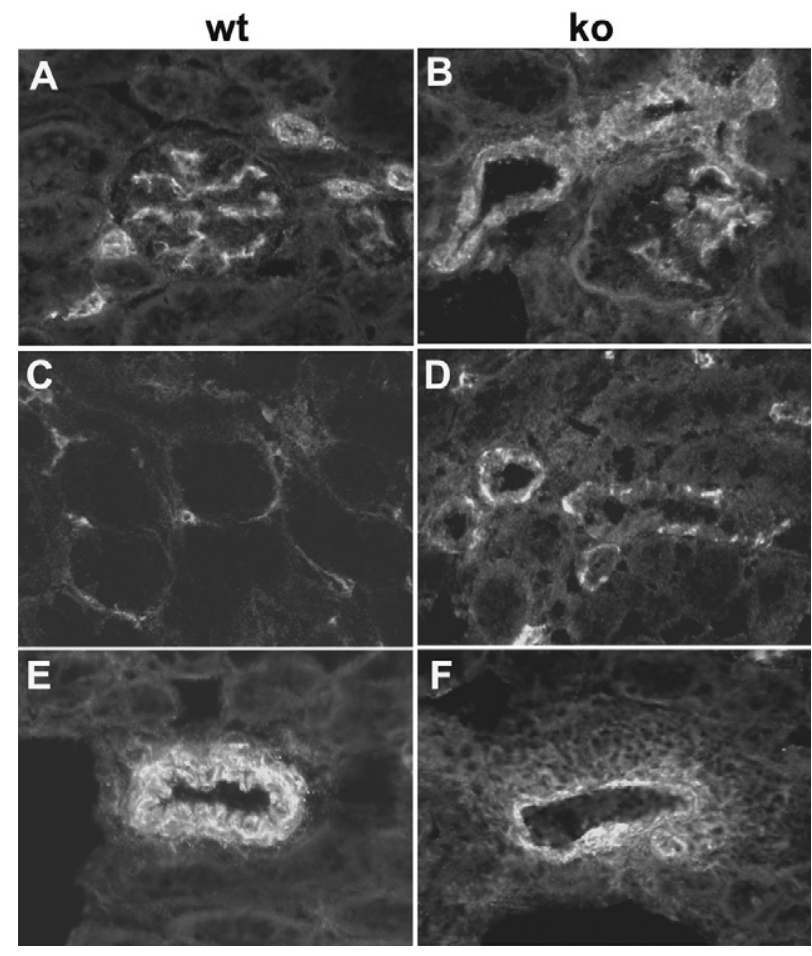

Figure 5. Pericyte staining. Samples from wt $(\mathbf{A}, \mathbf{C}, \mathbf{E})$ and ko $(\mathbf{B}, \mathbf{D}, \mathbf{F})$ mice were stained with antibody to NG2. Note the increased staining in the extra-glomerular mesangium and around afferent and efferent arterioles in $\mathbf{B}$. Note the enlarged vessels with discontinuous pericytes in $\mathbf{D}$. Note the large number of pericytes that surround, but are distant from the vessel wall in $\mathbf{F}$. 

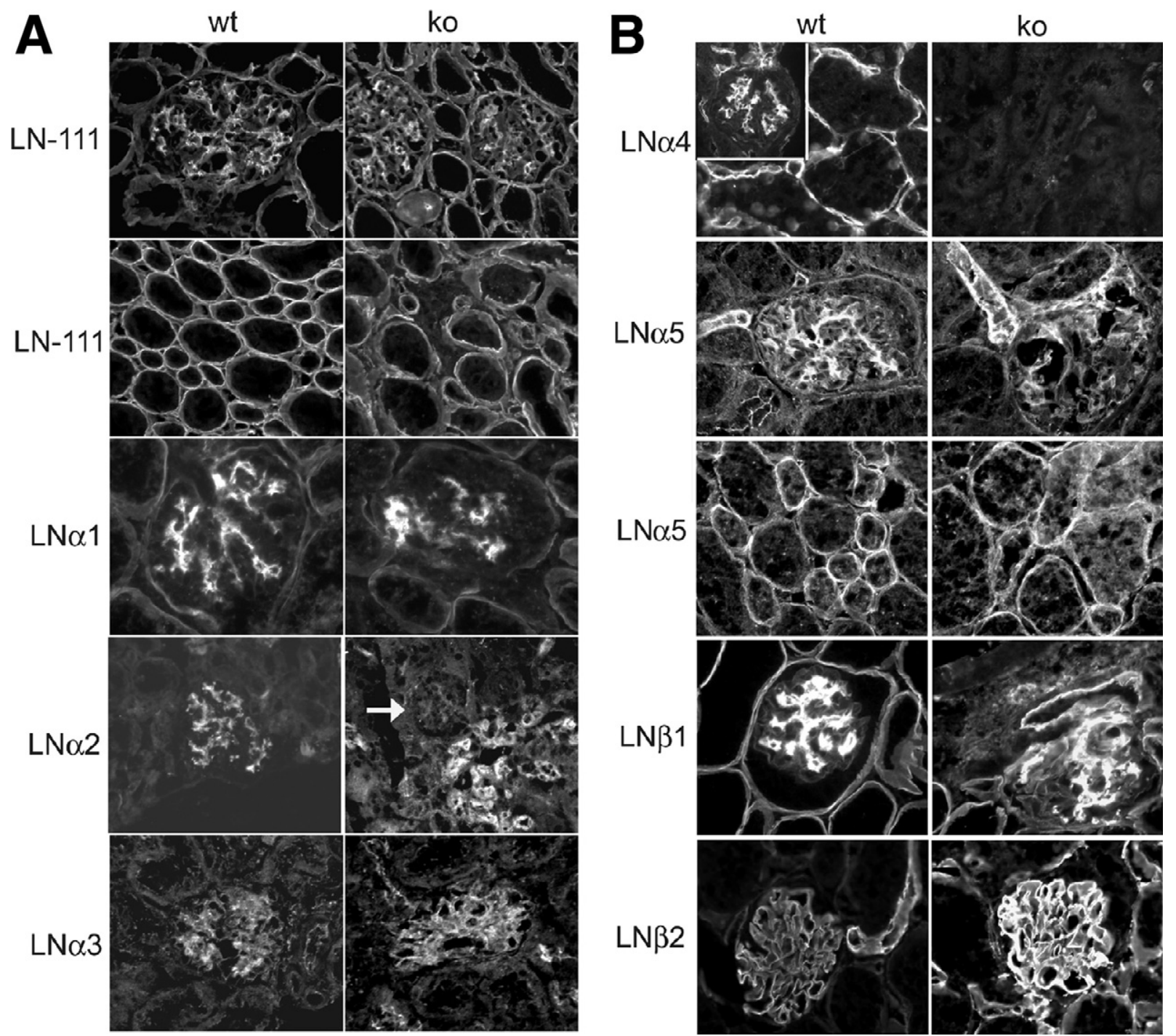

Figure 6. Immunofluorescence microscopy: patterns and transitions in laminin isoforms. Kidneys from wt and ko mice were stained with antibodies to the following proteins: A: LN111, LN $\alpha 1, \mathrm{LN} \alpha 2$, LN $\alpha 3$. Anti-LN111 stains all kidney basement membranes showing overall structure. Typically this antibody stains mesangial matrix more brightly than GBM. This was true in wild-type and lama4-/- mice. Note the irregular organization of mesangial matrix and wide separation between adjacent tubular basement membranes, which represents the space occupied by dilated peritubular capillaries. In the mouse, staining for LN $\alpha 1$ is normally detected in GBM at early stages of glomerulogenesis, and disappears from this site as glomerulogenesis is completed, with detectable LN $\alpha 1$ remaining in the mesangium and TBM of proximal tubules. These transitions in $\mathrm{LN} \alpha 1$ were identical in 7-to 14-week-old wild-type and lama4-/- mice. Note the absence of glomerular staining for $\mathrm{LN} \alpha 2$ in lama4-/- mice (arrow) and the increase in staining around afferent and efferent arterioles at the glomerular hilum. LN $\alpha 3$ has a limited distribution on the endothelial side of GBM. No significant change in $\mathrm{LN} \alpha 3$ was identified in lama4-/ - mice. B: $\mathrm{LN} \alpha 4, \mathrm{LN} \alpha 5, \mathrm{LN} \beta 1$, and $\mathrm{LN} \beta 2$. $\mathrm{LN} \alpha 4$ is detected in the mesangial matrix and surrounding peritubular capillaries in wild-type mice and is not detected in lama4-/- mice. During normal glomerulogenesis, LN $\alpha 5$ replaces LN $\alpha 1$ in the GBM and it facilitates maturation and condensation of the mesangium. LN $\alpha 5$ is a normal component of TBM and the peritubular capillary basement membrane. In lama4-/- mice, $\mathrm{LN} \alpha 5$ staining of GBM, mesangial matrix, TBM and peritubular capillaries was not different from wild-type mice; however, structural differences in the mesangium were apparent with staining for this LN chain. The brightly stained, condensed mature mesangium was not uniformly present in lama4-/- mice. As glomeruli become fully mature, LN $\beta 1$ in GBM is replaced by LN $\beta 2$. This transition occurred normally in lama4-/- mice. In wild-type and lama4-/- mice, LN $\beta 1$ persists in other ECM compartments including the mesangium and TBM. Adjacent to TBM, a fibrillar matrix that supports peritubular capillaries normally contains LN411 and LN511. Of note, LN $\beta 1$ was not detected in this location, but LN $\beta 2$ was abundant, which indicates that peritubular capillary matrix is altered and contains only LN521 in lama4-/- mice.

ECM compartment. In some renal diseases, the normal transitions and final composition are altered. ${ }^{33-36} \mathrm{Al}-$ though developmental transitions in expression of LN chains occurred in lama4-/- mice, notable alterations in some subunits occurred (Figure 6, A and B). Staining with antibody to LN111 shows irregular organization of mesangial matrix in lama4-/- mice. Wide separation between adjacent tubular basement membranes (TBM) representing the space occupied by dilated peritubular capillaries is apparent. Although the reported distribution of $\mathrm{LN} \alpha 4$ varies, ${ }^{37-39}$ the $\alpha 4$ subunit is usually detected in mesangial matrix and surrounding peritubular capillaries as seen in wild-type mice. As expected, LN $\alpha 4$ was not detected in lama4-/- mice.

As GBM matures, $L N \alpha 1$ and $L N \beta 1$ are replaced by $\mathrm{LN} \alpha 5$ and $\mathrm{LN} \beta 2$. $^{40,41} \mathrm{LN} \alpha 3$ is detected only on the subendothelial side of GBM. ${ }^{23}$ TBM is usually composed of $L N \alpha 1, L N \alpha 5$, and $L N \beta 1$. These normal patterns of $L N$ subunit staining in GBM and TBM are unaffected in lama4-1- mice. 
As the mesangium matures in wild-type mice, $\mathrm{LN} \alpha 1$ persists and $\mathrm{LN} \alpha 2, \mathrm{LN} \alpha 4$ and $\mathrm{LN} \alpha 5$ appear. As expected, $\mathrm{LN} \alpha 4$ was not detected in lama4-/- mice. $\mathrm{LN} \alpha 1$ and $\mathrm{LN} \alpha 5$ were present and irregularly distributed in keeping with structural changes described above. $\mathrm{LN} \alpha 2$, which is normally expressed in mature mouse mesangium, was not identified in glomeruli of lama4-/- mice, but instead was abundant in cells adjacent to afferent and efferent arterioles. In mice, $\mathrm{LN} \alpha 2$ is a product of MCs; thus, this observation suggests that MCs are abundant in the hilar region and adjacent to the afferent and efferent arterioles (extraglomerular mesangium), but less abundant in peripheral loops of the glomerulus. This coincides with the distribution of MCs described above.

Peritubular capillaries normally stain with antibodies to $\mathrm{LN} \alpha 4$, LN $\beta 1$, and lower amounts of $\mathrm{LN} \alpha 5$ (see wild-type mice in Figure 6). The appearance of $\mathrm{LN} \alpha 5$ at $1-3$ weeks after birth is reported to stabilize microvessels in other organs in the lama4-/- model (12); similar to those reports, peritubular capillaries remain dilated. New expression of $L N \beta 2$ was seen in the lama4-/- mice in the fibrillar matrix that supports peritubular capillaries. LN $\beta 1$ that is normally expressed in this location was not detected. We previously reported a similar change in focal capillaries around proximal tubules in individuals with transplant rejection. ${ }^{42}$ The functional significance of new expression of $L N \beta 2$ in this location is unknown, although similar transitions have been reported in other capillaries during active angiogenesis and microvessel maturation. ${ }^{7,43}$ The expression of $\mathrm{LN} \alpha 2$ and $\mathrm{LN} \alpha 5$ in the face of altered peripheral migration of MCs and poor pericyte investment of other microvessels argues that these $L N$ subunits cannot substitute for $\mathrm{LN} \alpha 4$ in mediating these functions.

\section{Growth Factor Expression Over Time in lama4-/- Mice}

Although microvessels form in lama4-/- mice, each of the changes described above indicate that there is poor pericyte investment and failure of vessel maturation. Normally, these processes are carefully orchestrated by sequential expression and down-regulation of a series of growth factors. During development, VEGF-A drives endothelial cell proliferation and migration. Then, endothelial cells secrete PDGF-BB, which recruits PDGF-R $\beta$ bearing pericytes to blood vessels and MCs to the glomerulus. ${ }^{31,44}$ As pericytes coat the expanding endothelial tubes, they initiate a series of reciprocal changes between the two cells that slow vessel growth and enhance cell differentiation. In keeping with this, VEGF and PDGF-BB are normally present in developing glomeruli, but, their expression is significantly reduced when maturation is complete. ${ }^{31}$ In lama4-/- mice 7-14 weeks of age, expression of VEGF, VEGFR2, VEGFR1, angiopoietin 2 (Ang2) and Tie2 were not different from wild-type mice (not shown); yet, PDGF-BB (mRNA and protein) and PDGF-R $\beta$ expression were significantly increased in glomerular and peritubular areas (Figure 7, A-J). These data indicate that reductions in pericyte coverage do not result
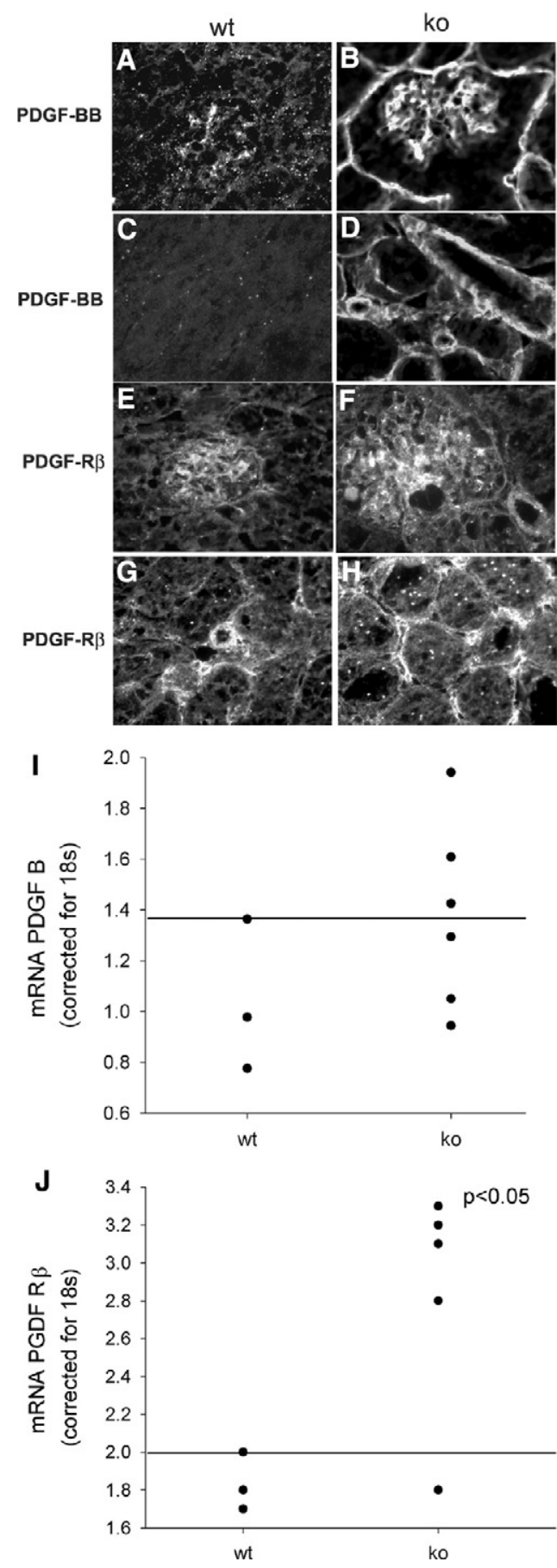

Figure 7. PDGF and PDGF-R $\beta$. Staining for PDGF-BB (A-D) and PDGF-R $\beta$ $(\mathbf{E}-\mathbf{H})$ are shown in wt $(\mathbf{A}, \mathbf{C}, \mathbf{E}, \mathbf{G})$ and $\operatorname{ko}(\mathbf{B}, \mathbf{D}, \mathbf{F}, \mathbf{H})$ mice. Note increased staining for both PDGF and PDGF-R $\beta$ in lama4 mice. qPCR for PDGF-B mRNA (I) and PDGF-R $\beta$ mRNA (J). mRNA in whole kidney cortex was determined by qPCR and corrected for 18S RNA. The line represents the upper value detected in normal mice. Note that mRNA for PDGF-R $\beta$ was significantly increased $(P<0.05)$ in ko mice.

from absence of PDGF/PDGF-R $\beta$; however, in the absence of $L N \alpha 4$, appropriate down-regulation of the PDGF/PDGF-R $\beta$ system that is normally associated with vessel maturation did not occur.

PDGF-BB is known to lead to glomerulosclerosis through stimulation of mesangial proliferation and an in- 

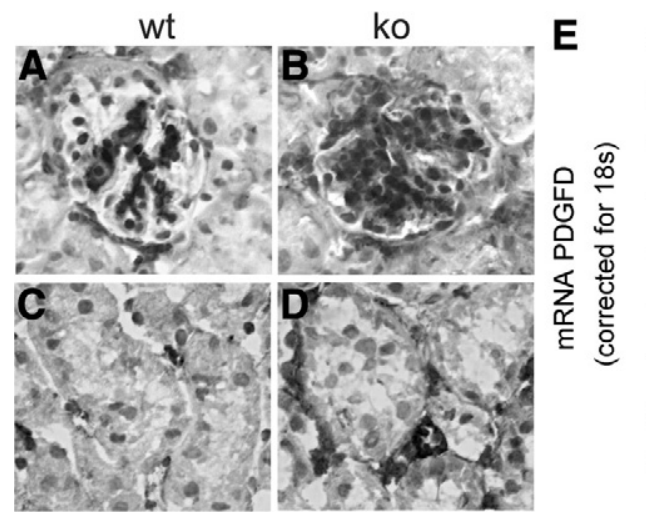

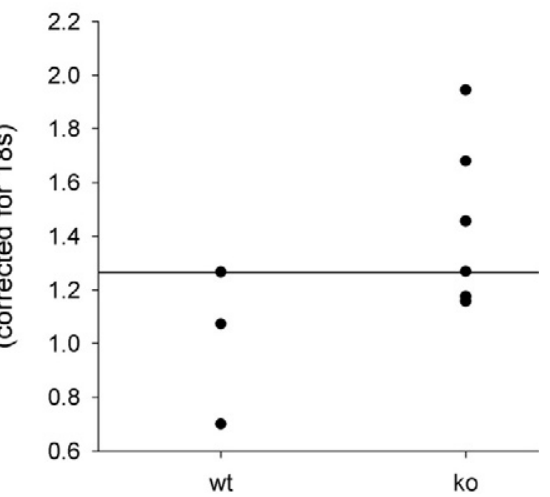

Figure 8. PDGF-DD. Staining for PDGF-DD shown in wt (A and $\mathbf{C}$ ) and ko ( $\mathbf{B}$ and $\mathbf{D})$ mice. Note increased staining in lama4-/- mice. E: PDGF-D mRNA. mRNA in whole kidney cortex was determined by qPCR corrected for 18S RNA. The line represents the upper value detected in normal mice. crease in matrix synthesis. PDGF-BB also contributes to interstitial fibrosis in a variety of kidney diseases. ${ }^{45,46}$ PDGF-BB may indirectly promote renal fibrosis as prolonged stimulation with PDGF-BB leads to transforming growth factor- $\beta$ and chemokine synthesis. ${ }^{45}$ Based on these known effects of PDGF-BB, and because the increase in PDGF-BB and PDGF-R $\beta$ observed in the first three months of life persisted as animals aged, we postulate that PDGF-BB contributes to the development of glomerulosclerosis and tubulointerstitial fibrosis in lama4-/- mice. There has been recent interest in the potential role of PDGF-CC and PDGF-DD in microvessel development and renal disease progression. ${ }^{45}$ Although we did not detect significant amounts of PDGF-CC in wild-type or lama4-/- mice (data not shown), distinct increases in PDGF-DD (mRNA or protein) were observed (Figure 8, A-E). In the context of the present studies, expression of both PDGF-BB and PDGF-DD could stimulate angiogenesis of peritubular capillaries, retard their maturation, and drive fibrosis in both the glomerulus and interstitium. As glomerulosclerosis and tubulointerstitial fibrosis develop, ischemia may stimulate the production of other cytokines that further aggravate fibrosis. The increases in VEGF-A and Ang2 that were observed in fibrotic kidneys in older lama4-/- mice (Figures 9, A-D, and 10, A-D) are likely a consequence of the earlier

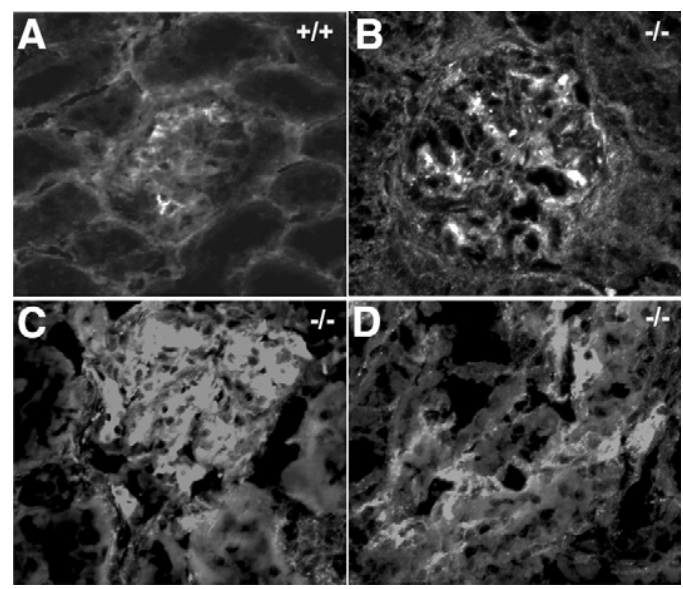

Figure 9. VEGF Staining. In lama $4-/-$ mice $(\mathbf{B}, \mathbf{C}, \mathbf{D})$ over 9 months of age, there was an increase in VEGF staining in both the glomerulus and peritubular capillaries as compared with wt mice $(\mathbf{A})$. changes, but they may contribute to progressive fibrosis as mice age.

\section{In Vitro Studies}

There is growing evidence that expression of LN411/421 is important for blood vessel growth and repair after development, ${ }^{7,13}$ although the mechanisms responsible for these effects are unknown. To investigate this process, we asked if $\mathrm{LN} \alpha 4$ expression played a direct role in controlling growth factor and/or growth factor receptor expression. MCs were cultured on plates coated with LN111 or LN411/421. mRNA was extracted and analyzed by qPCR, and cell lysates were analyzed by Western blot. MCs plated on LN411/421 exhibited marked down-regulation of PDGF-R $\beta$ mRNA and protein in comparison with cells plated on LN-111 (Figure 11). PDGF-BB mRNA was not detected in MCs plated on either substrate. Our previous findings showing that $\mathrm{LN} \alpha 4$ is required for PDGFinduced migration, ${ }^{15}$ indicate that pericyte investment
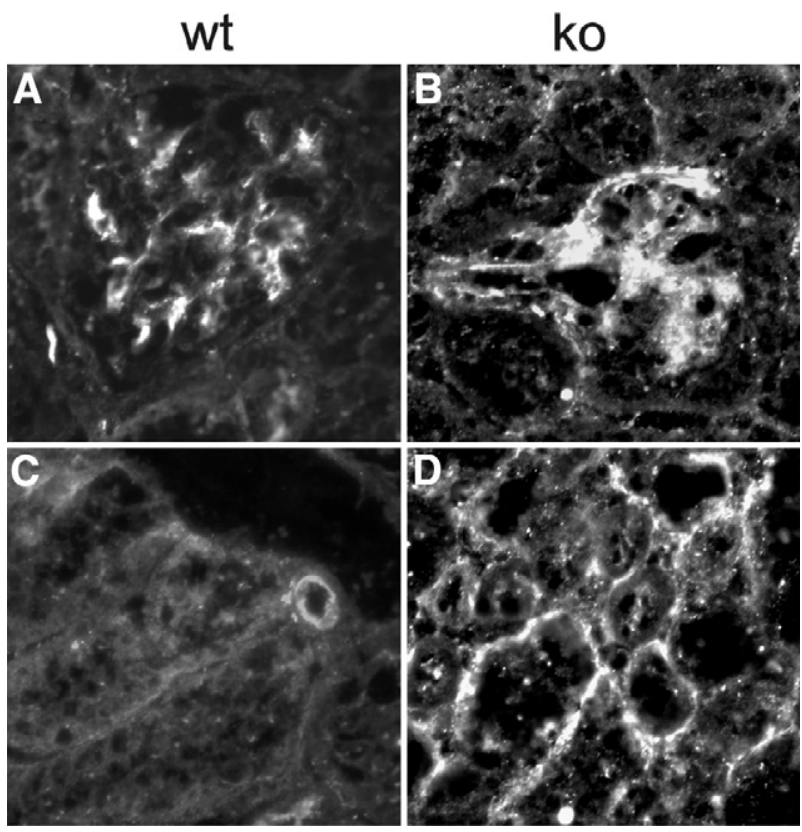

Figure 10. Angiopoietin 2 Staining. In animals over 9 months of age, there was a modest increase in Ang2 staining in both the glomerulus and peritubular capillaries in ko mice (B and $\mathbf{D})$ as compared with wt mice (A and $\mathbf{C})$. 


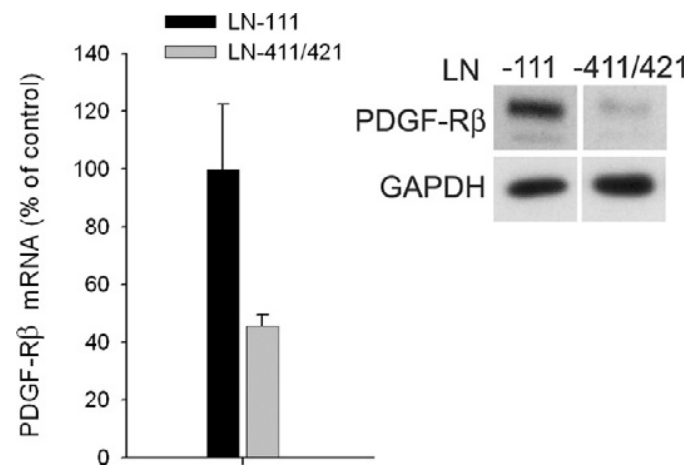

Figure 11. In vitro studies. Plating of MCs on LN411/421 as compared with LN111 was associated with a decrease in PDGF-R $\beta$ mRNA (bar graph, left) and protein (Western blot, right).

might be reduced when $\mathrm{LN} \alpha 4$ expression is reduced even when PDGF and PDGF-R $\beta$ are abundant. These findings complement those made in vivo and suggest that $\mathrm{LN} \alpha 4$ plays a role in pericyte recruitment and the cooperative interaction between these cells that promotes glomerular and blood vessel maturation.

\section{Discussion}

Evaluation of kidneys in lama4-/- mice shows reduced $\mathrm{MC} /$ pericyte investment of glomeruli and peritubular capillaries. With reduced pericyte investment, capillaries remain dilated, and PDGF/PDGF-R $\beta$, which can drive blood vessel growth and fibrosis are not appropriately downregulated. With time, glomerulosclerosis and tubulointerstitial fibrosis develop. In vitro studies support a role for LN411/421 in microvessel growth and maturation, ${ }^{7,13}$ including PDGF-BB-mediated MC migration ${ }^{15}$ and downregulation of PDGF-R $\beta$ expression. $\mathrm{LN} \alpha 4$ protects endothelial cells from apoptosis ${ }^{14}$; thus, without this subunit, endothelial loss ultimately contributes to ischemia driven fibrosis, particularly in the interstitium. This occurs at an earlier age in the heart than in the kidney. ${ }^{17}$ Recent evidence showing that mutations affecting $\mathrm{LN} \alpha 4$ expression contribute to the development of cardiomyopathy in humans suggests that these individuals may also be prone to kidney fibrosis. The rate of kidney fibrosis may be influenced by the frequency of minor injury to the kidney where microvessel repair is altered.

The role of angiogenic growth factors and their receptors in blood vessel and glomerular development has been extensively reviewed. ${ }^{47-49}$ Elegant studies from Quaggin and colleagues and others ${ }^{47,48}$ have established the importance of VEGF-A in endothelial proliferation and migration into the vascular cleft of the developing glomerulus and other blood vessels. ${ }^{50}$ Podocyte-derived angiopoietin-1 (Ang1) synergizes with VEGF to enhance proliferation and migration and prevent endothelial apoptosis via Tie2-mediated activation of PI3K/Akt. ${ }^{51}$ Regulated expression of various receptors also influences the sequence of vessel maturation. ${ }^{51}$ For example, VEGFR-2 initiates vasculogenic formation of glomerular endothelial cells (GEnC), whereas VEGFR-1 modulates development into blood vessels. ${ }^{51}$ Podocyte-GEnC inter- actions are critical in the early stages of glomerulogenesis and in maintenance of the slit diaphragm. ${ }^{52}$ These relationships appear normal in lama4-/- mice as the capillary wall formed normally, with appropriate transitions in ECM composition and no detectable changes in VEGF mRNA or protein.

GEnC-MC and podocyte-MC interactions are important for completion of glomerulogenesis and for repair in glomerular disease. ${ }^{53-55}$ Recruitment of mesangial progenitors into the developing glomerulus is dependent on GEnC secretion of PDGF-BB and MC expression of PDGFR $\beta .{ }^{16,56}$ Once pericytes or MC contact endothelial cells, they secrete Ang2, which antagonizes Ang1-mediated activation of Tie2 on endothelial cells, thereby suppressing endothelial cell proliferation and migration. ${ }^{57,58}$ PDGF plays a similar role in pericyte recruitment to vessels in other organs. ${ }^{44}$ VEGF remains cell-associated, presumably bound to $\mathrm{ECM},{ }^{59}$ where it increases the degree of pericyte coverage of capillaries. ${ }^{60}$ In turn, the density of pericyte investment influences the stability of endothelial cells and protects them from apoptosis. Normally, PDGF-BB secretion by endothelial cells falls following contact with pericytes, which in turn controls the density of pericyte investment. ${ }^{57}$ Contact with endothelial cells reduces pericyte expression of $\alpha \mathrm{SMA}$ and enhances expression of differentiation markers including desmin, smooth muscle myosin and NG2. ${ }^{61}$ These data show that reciprocal interactions between endothelial cells and pericytes determine the degree of pericyte investment of blood vessels and the maturation of both cell types. Disruption of the final stages of glomerular and blood vessel maturation with persistent overexpression of PDGF-BB and PDGF-R $\beta$ in lama4-/- mice suggest that LN411/LN421 are critical to this process.

Matrix attachment of PDGF and VEGF are required for, or enhance, the proliferative and migratory responses of cells to these growth factors. ${ }^{62,63}$ Although it is not known if $\mathrm{LN} \alpha 4$-containing isoforms bind, retain, and present growth factors to the cell, it is possible that lack of $\mathrm{LN} \alpha 4$ reduces or abolishes the effect of PDGF-BB on $\mathrm{MC} /$ pericyte proliferation, migration, or differentiation. We have shown that PDGF-BB-induced MC migration requires interaction with the $\mathrm{LN} \alpha 4$ chain of $\mathrm{LN} 411 .{ }^{15}$ This may explain the inadequate migration of MCs and pericytes despite abundant PDGF-BB, which is manifested by a reduction in MCs in the periphery of the glomerulus and an irregular pericyte investment in other microvessels. Without reciprocal interaction with endothelial cells, PDGF-R $\beta$ expression and that of other proangiogenic factors fail to be properly modulated to promote vessel maturation. Although much less is known about the biology of PDGF-DD, if it remains uncleaved following secretion, it can inhibit binding of PDGF-BB to the PDGF-R $\beta$. ${ }^{64}$ This might further prevent vessel maturation. Because PDGF-BB and PDGF-DD are potent growth factors that can induce progressive glomerulosclerosis and tubulointerstitial fibrosis when elevated expression persists, we postulate that continued overexpression of PDGF-BB and PDGF-DD contributes to the late stage of kidney fibrosis in the lama4-/- mice. The importance of $\mathrm{LN} \alpha 4$ to this process was shown in vitro, in which we found that $\mathrm{MC}$ 
exposure to LN411/421 directly led to PDGF-R $\beta$ down-regulation.

This report provides new insights into the cell and molecular mechanisms controlling the structure of the peritubular capillary. Normally these vessels are small, surrounded by fibrillar ECM composed of LN511 and LN411, with a limited number of pericytes. In lama4-/mice, there was an increase in LN521 with a reduction or loss of LN511. Only on rare occasions is LN $\beta 2$ detected in cortical peritubular capillaries. The significance of the increase in $L N \beta 2$ in this region is not known. As we have found that PDGF-BB does not induce a change in $L N \beta 2$ transcription or protein (data not shown), it suggests that other factors contribute to this change in LN $\beta 2$. Although the lack of $L N \alpha 4$ does not lead to major developmental abnormalities, it influences maturation of microvessels and responses to injury that could contribute to the degree and speed with which kidney fibrosis occurs. Similarities between cardiomyopathy observed in lama4-/mice and humans with mutations in this gene raise the possibility that these individuals will also develop abnormalities in their kidneys.

\section{Acknowledgments}

We appreciate the excellent technical assistance of Anne K. Berfield and thank the Seattle Mouse Metabolic Phenotyping Center and Dr. Charles Alpers for staining tissues for PDGF-DD.

\section{References}

1. Kleinman HK, Weeks BS, Schnaper HW, Kibbey MC, Yamamura K, Grant DS: The laminins: a family of basement membrane glycoproteins important in cell differentiation and tumor metastases. Vitamins Horm 1993, 47:161-186

2. Goldfinger LE, Stack MS, Jones JCR: Processing of laminin-5 and its functional consequences: role of plasmin and tissue-type plasminogen activator. J Cell Biol 1998, 141:255-265

3. Burgeson RE, Chiquet M, Deutzmann R, Ekblom P, Engel J, Kleinman H, Martin GR, Meneguzzi G, Paulsson M, Sanes J, Timpl R, Tryggvason K, Yamada Y, Yurchenco PD: A new nomenclature for the laminins. Matrix Biol 1994, 14:209-211

4. Yamashita H, Beck K, Kitagawa Y: Heparin binds to the laminin $\alpha 4$ chain LG4 domain at a site different from that found for other laminins. J Mol Biol 2004, 335:1145-1149

5. Talts JF, Sasaki T, Miosge N, Gohring W, Mann K, Mayne R, Timpl R: Structural and functional analysis of the recombinant $G$ domain of the laminin $\alpha 4$ chain and its proteolytic processing in tissues. J Biol Chem 2000, 275:35192-35199

6. Nomizu M, Song S-Y, Kuratomi Y, Tanaka M, Kim WH, Kleinman HK, Yamada Y: Active peptides from the carboxy-terminal globular domain of laminin $\alpha 2$ and Drosophila $\alpha$ chains. FEBS Lett 1996, 396:37-42

7. Hibino S, Shibuya M, Engbring JA, Mochizuki M, Nomizu M, Kleinman HK: Identification of an active site on the laminin $\alpha 5$ chain globular domain that binds to CD44 and inhibits malignancy. Cancer Res 2004, 64:4810-4816

8. Miner JH, Sanes JR: Collagen IV $\alpha 3, \alpha 4$, and $\alpha 5$ chains in rodent basal laminae: sequence, distribution, association with laminins, and developmental switches. J Cell Biol 1994, 127:879-891

9. Paulsson M, Saladin K: Mouse heart laminin. J Biol Chem 1989, 264:18726-18732

10. Marinkovich MP, Lundstrum GP, Keene DR, Burgeson RE: The dermal-epidermal junction of human skin contains a novel laminin variant. J Cell Biol 1992, 119:695-703
11. Engvall E, Earwicker D, Haaparanta T, Ruoslahti E, Sanes JR: Distribution and isolation of four laminin variants; tissue restricted distribution of heterotrimers assembled from five different subunits. Cell Regul 1990, $1: 731-740$

12. Thyboll J, Kortesmaa J, Cao R, Soininen R, Wang L, livanainen A, Sorokin L, Risling M, Cao Y, Tryggvason K: Deletion of the laminin $\alpha 4$ chain leads to impaired microvessel maturation. Mol Cell Biol 2002, 22:1194-1202

13. Zhou Z, Doi M, Wang J, Cao R, Liu B, Chan KM, Kortesmaa J, Sorokin $\mathrm{L}$, Cao Y, Tryggvason K: Deletion of laminin-8 results in increased tumor neovascularization and metastasis in mice. Cancer Res 2004 64:4059-4063

14. DeHahn KC, Gonzales M, Gonzalez AM, Hopkinson SB, Chandel NS, Brunelle JK, Jones JC: The $\alpha 4$ laminin subunit regulates endothelial cell survival. Exp Cell Res 2004, 294:281-289

15. Hansen KM, Abrass CK: Laminin-8/9 is synthesized by rat glomerular mesangial cells and is required for PDGF-induced mesangial cell migration. Kidney Int 2003, 64:110-118

16. Soriano P: Abnormal kidney development and hematological disorders in PDGF $\beta$-receptor mutant mice. Genes Dev 1994, 8:1888-1896

17. Wang J, Hoshijima M, Lam J, Zhou Z, Jokiel A, Dalton ND, Hultenby K, Ruiz-Lozano P, Ross J Jr, Tryggvason K, Chien KR: Cardiomyopathy associated with microcirculation dysfunction in laminin $\alpha 4$ chaindeficient mice. J Biol Chem 2006, 281:213-220

18. Patton BL, Cunningham JM, Thyboll J, Kortesmaa J, Westerblad H, Edstrom L, Tryggvason K, Sanes JR: Properly formed but improperly localized synaptic specializations in the absence of laminin alpha4. Nat Neurosci 2001, 4:597-604

19. Yang D, Bierman J, Tarumi YS, Zhong YP, Rangwala R, Proctor TM, Miyagoe-Suzuki Y, Takeda S, Miner JH, Sherman LS, Gold BG, Patton $\mathrm{BL}$ : Coordinate control of axon defasciculation and myelination by laminin-2 and -8. J Cell Biol 2005, 168:655-666

20. Wallquist W, Plantman S, Thams S, Thyboll J, Kortesmaa J, Lännergren J, Domogatskaya A, Ögren SO, Risling M, Hammarberg H, Tryggvason K, Cullheim S: Impeded interaction between Schwann cells and axons in the absence of laminin $\alpha 4$. J Neuro Sci 2005, 25:3692-3700

21. Abrass CK, Spicer D, Berfield AK, St John PL, Abrahamson DR Diabetes induces changes in glomerular development and laminin $\beta 2$ (s-laminin) expression. Am J Pathol 1997, 151:1131-1140

22. Hansen K, Berfield AK, Spicer D, Abrass CK: Rat mesangial cells express two unique isoforms of laminin which modulate mesangial cell phenotype. Matrix Biol 1998, 17:117-130

23. Abrass CK, Berfield AK, Ryan MC, Carter WG, Hansen KM: Abnormal development of glomerular endothelial and mesangial cells in mice with targeted disruption of the lama3 gene. Kidney Int 2006, 70:1062-1071

24. Kreisberg JI, Karnovsky MJ: Glomerular cells in culture. Kidney Int 1983, 23:439-447

25. Abrass CK, Spicer D, Raugi GJ: Induction of nodular sclerosis by insulin in rat mesangial cells in vitro: studies of collagen. Kidney Int 1995, 47:25-37

26. Abrass CK, Spicer D, Raugi GJ: Insulin induces a change in extracellular matrix glycoproteins synthesized by rat mesangial cells in culture. Kidney Int 1994, 46:613-620

27. Berfield AK, Hansen KM, Abrass CK: Rat glomerular mesangial cells require laminin-9 to migrate in response to insulin-like growth factor binding protein-5. Am J Physiol Cell Physiol 2006, 291:C589-C599

28. Arya M, Shergill IS, Williamson M, Gommersall L, Arya N, Patel HRH: Basic principles of real-time quantitative PCR. Exp Rev Mol Diagn 2005, 5:209-219

29. Rondaij MG, Bierings R, Kragt A, van Mourik JA, Voorberg J: Dynamics and plasticity of Weibel-Palade Bodies in endothelial cells. Arterioscler Thromb Vasc Biol 2006, 26:1002-1007

30. Witmer AN, van Blijswijk BC, van Noorden CJF, Vrensen GFJM, Schlingemann RO: In vivo angiogenic phenotype of endothelial cells and pericytes induced by vascular endothelial growth factor-A. J Histochem Cytochem 2004, 52:39-52

31. Alpers CE, Seifert RA, Hudkins KL, Johnson RJ, Bowen-Pope DF: Developmental patterns of PDGF B-chain. PDGF-receptor, and actin expression in human glomerulogenesis. Kidney Int 1992, 42:390-399

32. Abbate M, Zoja C, Rottoli D, Corna D, Tomasoni S, Remuzzi G: Proximal tubular cells promote fibrogenesis by TGF- $\beta 1$-mediated induction of peritubular myofibroblasts. Kidney Int 2002, 61:2066-2077

33. Abrahamson DR, St John PL: Loss of laminin epitopes during glo- 
merular basement membrane assembly in developing mouse kidneys. J Histochem Cytochem 1992, 40:1943-1953

34. Peutz-Kootstra CJ, Hansen K, de Heer E, Abrass CK, Bruijn JA: Differential expression of laminin chains and anti-laminin autoantibodies in experimental lupus nephritis. J Pathol 2000, 192:404-412

35. Abrahamson DR, Prettyman AC, Robert B, St John PL: Laminin-1 reexpression in Alport mouse glomerular basement membranes. Kidney Int 2003, 63:826-834

36. St John PL, Wang R, Yin Y, Miner JH, Robert B, Abrahamson DR: Glomerular laminin isoform transitions: errors in metanephric culture are corrected by grafting. Am J Physiol Renal Physiol 2001, 280:F695-F705

37. Petäjäniemi N, Korhonen M, Kortesmaa J, Tryggvason K, Sekiguchi K, Fujiwara H, Sorokin L, Thornell L-E, Wondimu Z, Assefa D, Patarroyo M, Virtanen I: Localization of laminin $\alpha 4$-chain in developing and adult human tissues. J Histochem Cytochem 2002, 50:1113-1130

38. Frieser M, Nockel H, Pausch F, Roder C, Hahn A, Deutzmann R, Sorokin LM: Cloning of the mouse laminin $\alpha 4$ CDNA. Expression in a subset of endothelium. Eur J Biochem 1997, 246:727-735

39. livanainen A, Kortesmaa J, Sahlberg C, Morita T, Thesleff I, Tryggvason K: Primary structure, developmental expression, and immunolocalization of the murine laminin $\alpha 4$ chain. J Biol Chem 1997, 272:27862-27868

40. Miner JH: Building the glomerulus: a matricentric view. J Am Soc Nephrol 2005, 16:857-861

41. Abrahamson DR, St John PL, Isom KS, Robert B, Miner JH: Partial rescue of glomerular laminin $\alpha 5$ mutations by wild-type endothelia produce hybrid glomeruli. J Am Soc Nephrol 2007, 18:2285-2293

42. Abrass CK, Berfield AK, Stehman-Breen C, Alpers CE, Davis CL: Unique changes in interstitial extracellular matrix composition are associated with rejection and cyclosporine toxicity in human renal allograft biopsies. Am J Kidney Dis 1999, 33:11-20

43. Takahashi S, Sakai J, Fujino T, Hattori H, Zenimaru Y, Suzuki J, Miyamori I, Yamamoto TT: The very low-density lipoprotein (VLDL) receptor: characterization and functions as a peripheral lipoprotein receptor. J Atheroscler Thromb 2004, 11:200-208

44. Abramsson A, Lindblom P, Betsholtz C: Endothelial and nonendothelia sources of PDGF-B regulate pericyte recruitment and influence vascular pattern formation in tumors. J Clin Invest 2003, 112:1142-1151

45. Floege J, Eitner F, Alpers CE: A new look at platelet-derived growth factor in renal disease. J Am Soc Nephrol 2008, 19:12-23

46. Eitner F, Bücher E, van Roeyen C, Kunter U, Rong S, Seikrit C, Villa L, Boor P, Fredriksson L, Bäckström G, Eriksson U, Östman A, Floege J Ostendorf T: PDGF-C is a proinflammatory cytokine that mediates renal interstitial fibrosis. J Am Soc Nephrol 2008, 19:281-289

47. Satchell SC, Mathieson PW: Angiopoietins: microvascular modulators with potential roles in glomerular pathophysiology. J Nephrol 2003 16:168-178

48. Eremina V, Sood M, Haigh J, Nagy A, Lajoie G, Ferrara N, Gerber H-P, Kikkawa Y, Miner JH, Quaggin SE: Glomerular-specific alterations of VEGF-A expression lead to distinct congenital and acquired renal diseases. J Clin Invest 2003, 111:707-716

49. Kolatsi-Joannou M, Li XZ, Suda K, Yuan HT, Woolf AS: Expression and potential role of angiopoietins and Tie-2 in early development of the mouse metanephros. Dev Dyn 2001, 222:120-126

50. Breier G, Albrecht U, Sterrer S, Risau W: Expression of vascular endothelial growth factor during embryonic angiogenesis and endothelial cell differentiation. Development 1992, 114:521-532

51. Woolf AS, Yuan HT: Angiopoietin growth factors and Tie receptor tyrosine kinases in renal vascular development. Pediatr Nephrol 2001, 16:177-184

52. Liu A, Dardik A, Ballermann BJ: Neutralizing TGF- $\beta 1$ antibody infusion in neonatal rat delays in vivo glomerular capillary formation. Kidney Int 1999, 56:1334:1348

53. Mattot V, Moons L, Lupu F, Chernavvsky D, Gomez RA, Collen D, Carmeliet P: Loss of the VEGF164 and VEGF188 isoforms impairs postnatal glomerular angiogenesis and renal arteriogenesis in mice. J Am Soc Nephrol 2002, 13:1548-1560

54. Masuda Y, Shimizu A, Mori T, Ishiwata T, Kitamura H, Ohashi R, Ishizaki M, Asano G, Sugisaki Y, Yamanaka N: Vascular endothelial growth factor enhances glomerular capillary repair and accelerates resolution of experimentally induced glomerulonephritis. Am J Pathol 2001, 159:599-608

55. Kang D-H, Joly AH, Oh S-W, Hugo C, Kerjaschki D, Gordon KL, Mazzali M, Jefferson JA, Hughes J, Madsen KM, Schreiner GF, Johnson RJ: Impaired angiogenesis in the remnant kidney model: i. Potential role of vascular endothelial growth factor and thrombospondin-1. J Am Soc Nephrol 2001, 12:1434-1447

56. Lindahl P, Johansson BR, Leveen P, Betsholtz C: Pericyte loss and microaneurysm formation in PDGF-B-deficient mice. Science 1997, 277:242-245

57. Korff T, Kimmina S, Martiny-Baron G, Augustin HG: Blood vessel maturation in a 3-dimensional spheroidal coculture model: direct contact with smooth muscle cells regulates endothelial quiescence and abrogates VEGF responsiveness. FASEB J 2001, 15:447-457

58. Yuan HT, SURI CHIT, Landon DN, Yancopoulos GD, Woolf AS: Angiopoietin-2 Is a site-specific factor in differentiation of mouse renal vasculature. J Am Soc Nephrol 2000, 11:1055-1066

59. Darland DC, Massingham LJ, Smith SR, Piek E, Saint-Geniez M D'Amore PA: Pericyte production of cell-associated VEGF is differentiation-dependent and is associated with endothelial survival. Dev Biol 2003, 264:275-288

60. Hagedorn M, Balke M, Schmidt A, Bloch W, Kurz H, Javerzat S Rousseau B, Wilting J, Bikfalvi A: VEGF coordinates interaction of pericytes and endothelial cells during vasculogenesis and experimental angiogenesis. Dev Dyn 2004, 230:23-33

61. Hirschi KK, Rohovsky SA, D'Amore PA: PDGF. TGF-beta, and heterotypic cell-cell interactions mediate endothelial cell-induced recruitment of $10 T 1 / 2$ cells and their differentiation to a smooth muscle fate. J Cell Biol 1998, 141:805-814

62. Lindblom P, Gerhardt H, Liebner S, Abramsson A, Enge M, Hellstrom M, Backstrom G, Fredriksson S, Landegren U, Nystrom HC, Bergstrom G Dejana E, Ostman A, Lindahl P, Betsholtz C: Endothelial PDGF-B retention is required for proper investment of pericytes in the microvessel wall. Genes Dev 2003, 17:1835-1840

63. Miralem T, Steinberg R, Price D, Avraham H: VEGF $_{165}$ requires extracellular matrix components to induce mitogenic effects and migratory response in breast cancer cells. Oncogene 2001, 20:5511-5524

64. Fredriksson L, Li H, Eriksson U: The PDGF family: four gene products form five dimeric isoforms. Cytokine Growth Factor Rev 2004, 15:197-204 